Nidhomul Haq Vol 3 No: 1 Maret 2018

ISSN 2503-1481

\title{
Partisipasi Masjid Dalam Mendorong Tata Kelola Sampah Pedesaan Di Desa Genteng Kulon Kecamatan Genteng Kabupaten Banyuwangi
}

\author{
Ahmad Izza Muttaqin \\ Dosen Institut Agama Islam Ibrahimy Banyuwangi \\ izzazen@gmail.com
}

\begin{abstract}
The discourse about Ahlu al-Sunnah wa al-Jamaah is still very interesting among academics. This term becomes an idol for every stream and is raised within the scope affirming its status as a surviving stream of the world and the hereafter (firqah al-Najiah). Ahlu al-Sunnah wa al-Jamaah became fertile because it is supported by the hadith of the Prophet who indeed came from 73 groups of Islam only one who survived the Ahlu alSunnah wa al-Jamaah group. Ahlu al-Sunnah wa al-Jamaah by Said Aqil as People who have a method of religious thinking that covers all aspects of life based on the foundations of moderation, maintaining balance and tolerance. Ahlu al-Sunnah wa al-Jamaah is a school that will become a Manhaj al-Fikr, as it is only an attempt to find a middle ground between the various streams. Ahlu al-Sunnah wa al-Jamaah there is no limitations and provisions that should be the same as Imam Abu Hasan al-Asy'ari or al-Maturidi but the pillars of Ahlu al-Sunnah wa al-Jamaah understand this must-have differences and opinions in interpreting the source of religion not become the gulf as long as still holding pillars (rukn) Ahlu al-Sunnah wa al-Jamaah namely the divinity (uluhiyah), apostles (Nubuwah) and the end (al-Ma'd).
\end{abstract}

Keywords: sampah pedesaan, tata kelola masjid, partisipasi

\section{A. PENDAHULUAN}

Persoalan lingkungan yang selalu menjadi isu besar di hampir seluruh wilayah perkotaan adalah masalah sampah. Sebelumnya Kompas 13 Agustus 2003 mengatakan bahwa laju pertumbuhan ekonomi di kota dimungkinkan menjadi daya tarik luar biasa bagi penduduk untuk hijrah ke kota (urbanisasi). Akibatnya jumlah penduduk semakin membengkak, konsumsi masyarakat perkotaan melonjak, yang pada akhirnya akan mengakibatkan jumlah sampah juga meningkat.

Pertambahan jumlah sampah yang tidak diimbangi dengan pengelolaan yang ramah lingkungan akan menyebabkan terjadinya perusakan dan pencemaran lingkungan. Lebih jauh lagi, penanganan sampah yang tidak komprehensif akan memicu terjadinya masalah sosial, seperti amuk massa, bentrok antar warga, pemblokiran fasilitas TPA.

Pertumbuhan jumlah sampah di kota-kota di Indonesia setiap tahun meningkat secara tajam. Sebagai contoh di Kota Bandung. Di kota ini, pada tahun 2005 volume sampahnya sebanyak $7.400 \mathrm{~m} 3$ per hari dan pada tahun 2006 telah mencapai $7.900 \mathrm{~m} 3$ per hari. Selain itu, di Jakarta, pada tahun 2005 volume sampah yang dihasilkan sebanyak $25.659 \mathrm{~m} 3$ per hari dan pada tahun 2006 telah mencapai 26,880 m3 per hari.

Desa-desa di Kabupaten Banyuwangi memiliki persoalan sampah hampir sama dengan fenomena tersebut. Meskipun telah banyak upaya yang telah dilakukan oleh Pemerintah Daerah (PEMDA) berupa gerakan-gerakan massa dalam bidang pengelolaan sampah misalnya gerakan bank sampah, gerakan sedekah sampah dan bantuan-bantuan pendanaan serta peralatan juga telah banyak dialokasikan untuk pengelolaan sampah tersebut. Problematika yang yang ada sebenarnya bisa diatasi jika ada keterlibatan banyak pihak dalam merancang pola pengelolaan lingkungan. 
Selain dimandatkan dalam peraturan perundangan sebenarnya ada institusi yang memiliki kekuatan besar namun masih terabaikan posisinya dan belum diperhitungkan dalam proses-proses perumusan kebijakan publik di tingkat desa. Pengeloalaan sampah merupakan persoalan publik yang menjadi sangat krusial dan akan menjadi bom waktu jika tidak segera diatasi.

Institusi yang memiliki kekuatan besar namun masih terabaikan posisinya dan belum diperhitungkan dimaksud tersebut adalah masjid. Pada masa kehidupan Rasulullah SAW, masjid menjadi sentral kegiatan umat muslim. Setidaknya ada tiga peran dan fungsi yang diperankan oleh masjid: pertama sebagai tempat Ubudiyah atau tempat peribadatan yakni Masjid menjadi pusat peribadatan kaum muslimin, khususnya shalat yang lima waktu; kedua, tempat Ijtimaiyyah atau perkumpulan sosial- kemasyarakatan yakni masjid berperan sebagai tempat memecahkan perkara sosial, berkumpul dan saling berdialog sehingga problematika yang terjadi di masyarakat dapat diselesaikan. Dan; ketiga tempat tarbiyah atau pendidikan yakni masjid menjadi tepat masyarakat mendapat pendidikan, pengajaran, bimbingan dan arahan dari para cerdik pandai.

Prof. Nazarudin Umar memperkuat argementasi ini dengan menyatakan bahwa Rasulullah tidak hanya menjadikan masjid sebagai tempat untuk pelaksanaan ibadah khusus, namun masjid juga dijadikan sebagai sarana melakukan pemberdayaan umat seperti tempat untuk pembinaan dan peyebaran agama Islam, kemudian sebagai tempat untuk mengobati orang sakit, tempat untuk mendamaikan orang-orang yang bertikai, tempat untuk latihan perang (militer), tempat untuk menyampaikan pengumuman penting dan lain lain. Bahkan dalam masa keemasan Islam "Dulu universitas ada di dalam masjid, sekarang masjid di dalam universitas". Apa yang disampaikan Nasarudin Umar tersebut tentunya dapat menjadi acuan bagi pengembangan peran dan fungsi masjid secara holistic dan beradaptasi dengan perkembangan ilmu pengetahuan dan teknologi guna mewujudkan masyarakat yang berdaya dan mandiri.
Komunitas Umat Islam yang diberdayakan tidak dipandang sebagai komunitas yang menjadi objek pasif penerima pelayanan, melainkan sebuah komunitas yang memiliki beragam potensi dan kemampuan yang dapat diberdayakan.

Kegiatan pemberdayaan umat Islam (mustahil) dapat dilakukan melalui pendampingan dengan memberikan motivasi, meningkatkan kesadaran, membina aspek pengetahuan dan sikap meningkatkan kemampuan memobilisasi sumber produktif dan mengembangkan jaringan.

\section{B. HASIL DAN PEMBAHASAN}

\section{Kajian Peran Masjid Dalam Tata Kelola} Sampah Pedesaan

\section{Partisipasi Masjid Partisipasi}

Partisipasi dalam kamus besar Bahasa Indonesia yaitu tindakan ikut mengambil bagian, keikutsertaan atau ikut serta. Menurut Juliantara (2004:84) partisipasi diartikan sebagai keterlibatan setiap warga negara yang mempunyai hak dalam pembuatan keputusan, baik secara langsung maupun melalui intermediasi institusi legitimasi yang mewakili kepentingannya, partisipasi masyarakat merupakan kebebasan dan berbicara dan berpartisipasi secara konstruktif.

Konsep partisipasi mencakup kerjasama antara semua unsur terkait dan merupakan suatu kesepakatan, harapan, persepsi dan sistem komunikasi dimana kemampuan dan pendidikan mempengaruhi sikap dan cara berprilaku seseorang. Partisipasi berarti "mengambil bagian", atau menurut Hoofsteede dalam Khairuddin (2000: 124) "the taking part in one of more phases of the process" (partisipasi berarti ambil bagian dalam suatu tahap atau lebih dari suatu proses). Proses yang dimaksud dalam tulisan ini tentu saja proses pembangunan.

Partisipasi menurut Keith Davis (dalam Khairuddin, 2000: 124) yang dimaksud partisipasi adalah "as mental and emotional inovolment of person in a group situation which encourages him to contribute to group goals and share responsibility in them" (keterlibatan pikiran dan emosi seseorang dalam situasi 
kelompok yang memberikan semangat untuk menyokong kepada tujuan-tujuan kelompok dan mengambil bagian tanggung jawab untuk kelompok itu sendiri).

Partisipasi masyarakat (public participation) pada tatanan pemerintahan yang demokratis menghendaki adanya keterlibatan publik dalam proses pengambilan keputusan (decision-making process) yang semakin penting di era otonomi daerah. Pelaksanaan otonomi daerah berdasarkan Undang-Undang Republik Indonesia Nomor 32 Tahun 2004 tentang Pemerintahan Daerah (UU No. 32-2004), telah membawa perubahan besar dalam setiap segmen penyelenggaraan Pemerintahan Daerah.

Menurut Patton (2005: 88) mengemukakan bahwa "inisiatif atau prakarsa dalam berpartisipasi bisa berasal dari bawah atau masyarakat itu sendiri (bottom up) dan berasal dari pemerintah (top down). Di mana dalam pembangunan desa atau kelurahan bentuk swadaya yang berupa prakarsa dan inisiatif merupakan titik awal dari partisipasi masyarakat".

Menurut T.B. Simatupang dalam Khairuddin (2000: 124) memberikan beberapa rincian tentang partisipasi sebagai berikut :

a) Partisipasi berarti apa yang kita jalankan adalah bagian dari usaha bersama yang dijalankan bahu membahu dengan saudara kita sebangsa dan setanah air untuk membangun masa depan bersama.

b) Partisipasi berarti pula sebagai kerja untuk mencapai tujuan bersama diantara semua warga negara yang mempunyai latar belakang kepercayaan yang beraneka ragam dalam negara Pancasila kita, atau dasar hak dan kewajiban yang sama untuk memberikan sumbangan demi terbinanya masa depan yang baru dari bangsa kita.

c) Partisipasi tidak hanya berarti mengambil bagian dalam pelaksanaanpelaksanaan rencana pembangunan. Partisipasi berarti memberikan sumbangan agar dalam pengertian kita mengenai pembangunan itu, nilai-nilai kemanusiaan dan cita-cita mengenai keadilan sosial tetap dijunjung tinggi.

d) Partisipasi dalam pembangunan berarti mendorong ke arah pembangunan

yang serasi dengan martabat manusia. Keadilan sosial dan keadilan nasional dan yang memelihara alam sebagai lingkungan hidup manusia, juga untuk generasi-generasi yang akan datang.

Partisipasi melibatkan lebih banyak mental dan emosi daripada fisik seseorang, sehingga pribadinya diharapkan lebih banyak terlibat dari pada fisiknya sendiri. Partisipasi yang didorong oleh mental dan emosi yang demikian itu, disebut sebagai partisipasi "sukarela". Sedangkan partisipasi dengan paksaan disebut mobilisasi. Partisipasi mendorong orang untuk ikut bertanggung jawab di dalam suatu kegiatan, karena apa yang disumbangkannya adalah atas dasar kesukarelaan sehingga timbul rasa bertanggung jawab kepada organisasi.

\section{Bentuk Partisipasi}

Ada beberapa bentuk partisipasi dalam suatu program pembangunan, dapat dikelompokkan menjadi 2 jenis, yaitu bentuk partisipasi yang diberikan dalam bentuk nyata (memiliki wujud) dan juga bentuk partisipasi yang diberikan dalam bentuk tidak nyata (abstrak). Bentuk partisipasi yang nyata misalnya uang, harta benda, tenaga sedangkan bentuk partisipasi yang tidak nyata adalah partisipasi buah pikiran, pengambilan keputusan dan partisipasi representatif.

Menurut Holil (dalam Isbandi, 2007:21) mengemukakan adanya beberapa bentuk partisipasi, antara lain : (a) Partisipasi dalam bentuk tenaga adalah partisipasi masyarakat yang diberikan dalam bentuk tenaga untuk pelaksanaan usaha-usaha yang dapat menunjang keberhasilan suatu program. (b) Partisipasi dalam bentuk uang adalah 
bentuk partisipasi masyarakat yang diberikan untuk Studi Tentang Partisipasi Masyarakat Dalam Pembangunan (Dea Deviyanti) memperlancar usaha-usaha bagi pencapaian suatu program pembangunan. Partisipasi ini dapat berupa sumbangan berupa uang tetapi tidak dipaksakan yang diberikan oleh sebagian atau seluruh masyarakat untuk suatu kegiatan atau program pembangunan. (c) Partisipasi dalam bentuk harta benda adalah partisipasi masyarakat yang diberikan dalam bentuk menyumbang harta benda, biasanya berupa alat-alat kerja atau perkakas.

Sedangkan Adapun menurut Chapin (dalam abe, 2002:43) mengemukakan adanya bentuk partisipasi masyarakat, antara lain : (a) Partisipasi uang adalah bentuk partisipasi untuk memperlancar usaha-usaha bagi pencapaian kebutuhan masyarakat yang memerlukan bantuan. (b) Partisipasi buah pikiran adalah partisipasi berupa sumbangan berupa ide, pendapat atau buah pikiran konstruktif, baik untuk menyusun program maupun untuk memperlancar pelaksanaan program dan juga untuk mewujudkannya dengan memberikan pengalaman dan pengetahuan guna mengembangkan kegiatan yang diikutinya. (c) Partisipasi dalam proses pengambilan keputusan. Masyarakat terlibat dalam setiap diskusi/forum dalam rangka untuk mengambil keputusan yang terkait dengan kepentingan bersama. (d) Partisipasi representatif. Partisipasi yang dilakukan dengan cara memberikan kepercayaan/mandat kepada wakilnya yang duduk dalam organisasi atau panitia.

\section{Tingkatan Partisipasi Masyarakat}

Untuk pengembangan partisipasi masyarakat, perlu pemahaman dasar mengenai tingkatan partisipasi. Menurut Cohen dan Uphoff dikutip oleh Soetomo (2008:12) membagi partisipasi masyarakat dalam pembangunan ke dalam 4 tingkatan, yaitu : (a) Partisipasi dalam perencanaan yang diwujudkan dengan keikutsertaan masyarakat dalam rapat-rapat. Sejauh mana masyarakat dilibatkan dalam proses penyusunan dan penetapan program pembangunan dan sejauh mana masyarakat memberikan sumbangan pemikiran dalam bentuk saran untuk pembangunan. (b) Partisipasi dalam pelaksanaan dengan wujud nyata partisipasi berupa: partisipasi dalam bentuk tenaga, partisipasi dalam bentuk uang, partisipasi dalam bentuk harta benda. (c) Partisipasi dalam pemanfaatan hasil, yang diwujudkan keterlibatan seseorang pada tahap pemanfaatan suatu proyek setelah proyek tersebut selesai dikerjakan. Partisipasi masyarakat pada tingkatan ini berupa tenaga dan uang untuk mengoperasikan dan memelihara proyek yang telah dibangun. (d) Partisipasi dalam evaluasi, yang diwujudkan dalam bentuk keikutsertaan masyarakat dalam menilai serta mengawasi kegiatan pembangunan serta hasil-hasilnya. Penilaian ini dilakukan secara langsung, misalnya dengan ikut serta dalam mengawasi dan menilai atau secara tidak langsung, misalnya memberikan saran-saran, kritikan atau protes.

Faktor Pendukung dan Faktor Penghambat Partisipasi

Ada beberapa faktor yang dapat mendukung dan menghambat partisipasi masyarakat dalam suatu program, Timbulnya partisipasi merupakan ekspresi perilaku manusia untuk melakukan suatu tindakan, dimana perwujudan dari perilaku tersebut didorong oleh adanya tiga faktor utama yang mendukung, yaitu (1) kemauan; (2) kemampuan; dan (3) kesempatan bagi masyarakat untuk berpartisipasi, Dorodjatin (dalam Slamet, 2003:18). Selain itu ada juga factor yang menghambat partisipasi masyarakat menurut Watson (dalam Soetomo, 2008:214) mengatakan bahwa ada beberapa kendala (hambatan) yang dapat menghalangi terjadinya suatu perubahan antara lain kendala yang berasal dari kepribadian individu salah satunya adalah ketergantungan. Ketergantungan masyarakat terhadap pemerintah dalam pelaksanaan kegiatan pembangunan merupakan hambatan dalam mewujudkan partisipasi atau keterlibatan masyarakat secara aktif, karena rasa ketergantungan 
ini masyarakat tidak memiliki inisiatif untuk melaksanakan pembangunan atau prakarsa mereka sendiri. Faktor-faktor yang menghambat partisipasi masyarakat tersebut dapat dibedakan dalam factor internal dan faktor eksternal, dijelaskan sebagai berikut :

a) Faktor internal

Menurut Slamet (2003:137143), untuk faktor-faktor internal adalah berasal dari dalam kelompok masyarakat sendiri, yaitu individuindividu dan kesatuan kelompok didalamnya. Tingkah laku individu berhubungan erat atau ditentukan oleh ciri-ciri sosiologis seperti umur, jenis kelamin, pengetahuan, pekerjaan dan penghasilan. Secara teoritis, terdapat hubungan antara ciri-ciri individu dengan tingkat partisipasi, seperti usia, tingkat pendidikan, jenis pekerjaan, lamanya menjadi anggota masyarakat, besarnya pendapatan, keterlibatan dalam kegiatan pembangunan akan sangat berpengaruh pada partisipasi. Sedangkan,

b) Faktor-faktor Eksternal

Menurut Sunarti (dalam jurnal Loka, 2003:9), faktor-faktor eksternal ini dapat dikatakan petaruh (stakeholder), yaitu Dalam hal ini stakeholder yang mempunyai kepentingan dalam program ini adalah pemerintah daerah, pengurus desa/kelurahan (RT/RW), tokoh masyarakat/adat dan konsultan/fasilitator. Petaruh kunci adalah siapa yang mempunyai pengaruh yang sangat signifikan, atau mempunyai posisi penting guna kesuksesan program.

\section{Partisipasi Masjid}

Masjid atau mesjid adalah rumah tempat ibadah umat Muslim. Masjid artinya tempat sujud, dan mesjid berukuran kecil juga disebut musholla, langgar atau surau. Selain tempat ibadah masjid juga merupakan pusat kehidupan komunitas muslim. Kegiatan - kegiatan perayaan hari besar, diskusi, kajian agama, ceramah dan belajar Al Qur'an sering dilaksanakan di Masjid. Bahkan dalam sejarah Islam, masjid turut memegang peranan dalam aktivitas sosial kemasyarakatan hingga kemiliteran (_masjid.

https://id.wikipedia.org/wiki/Masjid. Diakses 20 Oktober 2016).

Secara bahasa, kata masjid (مَسْحْدِ adalah tempat yang dipakai untuk bersujud. Kemudian maknanya meluas menjadi bangunan khusus yang dijadikan orang-orang untuk tempat berkumpul menunaikan shalat berjama'ah. AzZarkasyi berkata, "Manakala sujud adalah perbuatan yang paling mulia dalam shalat, disebabkan kedekatan hamba Allah kepada-Nya di dalam sujud, maka tempat melaksanakan shalat diambil dari kata sujud (yakni masjad = tempat sujud). Mereka tidak menyebutnya مَرْ كَع (tempat ruku') atau yang lainnya. Kemudian perkembangan berikutnya lafazh masjad berubah menjadi masjid, yang secara istilah berarti bengunan khusus yang disediakan untuk shalat lima waktu. Berbeda dengan tempat yang digunakan untuk shalat 'Id atau sejenisnya (seperti shalat Istisqa') yang dinamakan آلَدُصَّلى (mushallaa $=$ lapangan terbuka yang digunakan untuk shalat 'Id atau sejenisnya). Hukum-hukum bagi masjid tidak dapat diterapkan pada mushalla (alAsfahani, Tt : 397). Istilah masjid menurut syara' adalah tempat yang disediakan untuk shalat di dalamnya dan sifatnya tetap, bukan untuk sementara.

Di zaman Rasulullah masjid bisa berfungsi sebagai halaqoh, yakni untuk mendiskusikan berbagai macam permasalahan umat bahkan menjadi bagian dari perumusan kegiatan politik. Peran masjid menjadi dinamis dan berfungsi mendorong tumbuhkembangnya keberdayaan umat. Mengacu pada tradisi kenabian tersebut sebenarnya masjid dapat berkembang lebih luas menjangkau pengayaan sumberdaya umat melalui bentuk bentuk kegiatan yang bersinergi antara praktik - praktik keberagamaan dan kehidupan umat di sekitar masjid.

Selama ini masjid masih dikembangkan terbatas pada kegiatan keagamaan yang bersifat mahdah, 
meskipun kegiatan - kegiatan keagamaan yang lain juga tercakup didalamnya seperti sebagai tempat pendidikan Al Qur'an, halaqoh diniyah, pengajian dan sebagainya. Seiring dengan waktu sumberdaya yang ada di masjid juga mulai disentuh, misalnya diaspek pemberdayaan menegemen kemasjidan . perkembangan ini merupakan arah positif untuk memaksimalkan fungsi masjid sebagai bagian dari pelayanan ummat. Namun demikian peningkatan tersebut belum maksimal karena berhadapan dengan situasi-situasi kontraproduktif antara fungsi pelayanan dan kebutuhan akan layanan serta kapasitas orang-orang yang siap mendedikasikan diri untuk menjadi pelayan ummat sekaligus ketrampilan mengorganisasi komunitas sekaligus memvariasikan da'wah masjid yang menyentuh berbagai aspek kehidupan dan kebutuhan ummat.

Partisipasi masjid yang dimaksud dalam penelitian ini adalah peran aktif takmir masjid, remaja masjid dan masyarakat di sekitar masjid dalam menginisiasi dan berpartisipasi aktif dalam tata kelola sampah pedesaan di Desa Genteng Kulon Kecamatan Genteng Kabupaten Banyuwangi.

\section{Tata kelola sampah pedesaan Sampah} Pedesaan

Sampah merupakan sisa dari kehidupan, yang sering menimbulkan masalah, dan jumlahnya akan semakin meningkat seiring dengan peningkatan jumlah penduduk dan beragam aktivitasnya. Peningkatan jumlah penduduk berarti peningkatan jumlah timbulan sampah, dan semakin beragam aktivitas berarti semakin beragam jenis sampah yang dihasilkan. Karenanya, sampah harus mulai dipandang sebagai sumber daya. Ini berarti kebiasaan membuang harus diubah menjadi mengolah sampah. Sampah adalah Barang bekas atau sesuatu yang tidak dikehendaki lagi oleh yang punya dan bersifat padat. Sementara didalam UU No 18 Tahun 2008 tentang Pengelolaan Sampah, disebutkan sampah adalah sisa kegiatan sehari hari manusia atau proses alam yang berbentuk padat atau semi padat berupa zat organik atau anorganik bersifat dapat terurai atau tidak dapat terurai yang dianggap sudah tidak berguna lagi dan dibuang kelingkungan.

Sampah dalam ilmu kesehatan lingkungan sebenarnya hanya sebagian dari benda atau hal-hal yang dipandang tidak digunakan, tidak dipakai, tidak disenangi, atau harus dibuang sedemikian rupa sehingga tidak sampai menganggu kelangsungan hidup. Sampah merupakan material sisa yang tidak diinginkan setelah berakhirnya suatu proses. Secara umum jenis sampah dapat dibagi menjadi dua yaitu sampah organik dan an-organik. Sampah organik adalah sampah yang berasal dari makluk hidup seperti daundaunan dan sampah dapur dan sampah jenis ini dapat membusuk atau hancur secara alami sedangkan sampah kering (an-organik) seperti kertas, plastik, dan kaleng sulit untuk dapat terdegradasi (membusuk/hancur) secara alami.

Menurut Subarna (2014) sampah secara spesifik dibagi menjadi duabelas karakteristik yaitu sebagai berikut : 1 . Garbage Garbage yaitu jenis sampah yang terdiri dari sisa-sisa potongan hewan atau sayuran dari hasil pengolahan yang sebagian besar terdiri dari zat-zat yang mudah membusuk, lembab, dan mengandung sejumlah air bebas. 2 . Rubbish Rubbish terdiri dari sampah yang dapat terbakar atau yang tidak dapat terbakar yang berasal dari rumah-rumah, pusat-pusat perdagangan, kantor-kantor, tapi yang tidak termasuk garbage. 3. Ashes (Abu) Ashes (Abu) yaitu sisa-sisa pembakaran dari zat-zat yang mudah terbakar baik dirumah, dikantor, dan industri.

Sampah adalah bahan yang tidak mempunyai nilai atau tidak berharga untuk maksud biasa atau utama dalam pembikinan atau pemakaian barang rusak atau bercacat dalam pembuatan manufaktur atau materi berkelebihan atau ditolak atau buangan. Sampah dalam ilmu kesehatan lingkungan sebenarnya hanya sebagian dari benda atau hal-hal yang dipandang tidak digunakan, tidak dipakai, tidak disenangi, atau harus dibuang, sedemikian rupa sehingga tidak sampai 
mengganggu kelangsungan hidup. Dari segi ini dapat disimpulkan bahwa yang dimaksud dengan sampah ialah sebagian dari sesuatu yang tidak dipakai, disenangi atau sesuatu yang harus dibuang, yang umumnya berasal dari kegiatan yang dilakukan oleh manusia (termasuk kegiatan industri), tetapi yang bukan biologis (karena human waste tidak termasuk didalamnya) dan umumnya bersifat padat (karena air bekas tidak termasuk di dalamnya).

\section{Dampak Negatif Sampah}

Sampah padat yang bertumpuk banyak tidak dapat teruraikan dalam waktu yang lama akan mencemarkan tanah. Yang dikategorikan sampah disini adalah bahan yang tidak dipakai lagi (refuse) karena telah diambil bagianbagian utamanya dengan pengolahan menjadi bagian yang tidak disukai dan secara ekonomi tidak ada harganya.

Ada tiga dampak sampah terhadap manusia dan lingkungan yaitu :

- Dampak Terhadap Kesehatan

Lokasi dan pengelolaan sampah yang kurang memadai (pembuangan sampah yang tidak terkontrol) merupakan tempat yang cocok bagi beberapa organisme dan menarik bagi berbagai binatang seperti, lalat dan anjing yang dapat menjangkitkan penyakit. Potensi bahaya kesehatan yang dapat ditimbulkan adalah sebagai berikut -Penyakit diare, kolera, tifus menyebar dengan cepat karena virus yang berasal dari sampah dengan pengelolaan tidak tepat dapat bercampur air minum.

- Dampak Terhadap Lingkungan

Cairan rembesan sampah yang masuk kedalam drainase atau sungai akan mencemari air. Berbagai organisme termasuk ikan dapat mati sehingga beberapa spesien akan lenyap, hal ini mengakibatkan berubahnya ekosistem perairan biologis. Penguraian sampah yang di buang kedalam air akan menghasilkan asam organik dan gas cair organik, seperti metana. Selain berbau kurang sedap, gas ini pada konsentrasi tinggi dapat meledak.
- Dampak Terhadap Keadaan Sosial dan Ekonomi

Dampak-dampak tersebut adalah sebagai berikut : a. Pengelolaan sampah yang tidak memadai menyebabkan rendahnya tingkat kesehatan masyarakat. Hal penting disini adalah meningkatnya pembiayaan (untuk mengobati kerumah sakit). Infrastruktur lain dapat juga dipengaruhi oleh pengelolaan sampah yang tidak memadai, seperti tingginya biaya yang diperlukan untuk pengolahan air. Jika sarana penampungan sampah kurang atau tidak efisien, orang akan cenderung membuang sampahnya dijalan. Hal ini mengakibatkan jalan perlu lebih sering dibersihkan dan diperbaiki.

\section{Pengelolaan Sampah}

Menurut Subarna (2014: 43) sistem pengelolaan sampah dibagi menjadi lima metode yaitu sebagai berikut :

1) Metode Daur Ulang

Metode daur ulang merupakan suatu proses pengambilan kembali barang yang masih memiliki nilai ekonomis dan dapat dimanfaatkan untuk digunakan kembali sebagaimana yang diinginkan oleh pengolahnya. Umumnya metode daur ulang ini digunakan untuk mengambil bahan baku dari sampah untuk diproses kembali atau mengambil kalori dari bahan-bahan yang masih berfungsi dari sampah tersebut dan bermanfaat untuk proses produksi produk baru lainnya.

2) Metode Pengolahan Kembali Secara Fisik

Metode pengolahan kembali secara fisik sebenarnya memiliki spesifikasi yang sama dengan metode daur ulang namun yang berbeda yaitu metode pengolahannya. Metode pengolahan sampah kembali secara fisik hanya melakukan kegiatan pembersihan ataupun memanfaatkan kembali sampah tersebut sebagaimana fungsinya sebelumnya. 
3) Metode Pengolahan Biologis

Metode pengolahan biologis yang dimaksud yaitu pengolahan sampah dilakukan secara alamiah dan umunya dimanfaatkan sebagai bahan untuk membuat pupuk kompos atau mengambil zat-zat yang terkandung dalam sampah tersebut sebagai energi alternatif pembangkit listrik ataupun pengganti energi pokok rumah tangga. Sampah yang dapat dimanfaatkan hanya sampah dengan jenis organik dan sampah nonorganik yang tidak dapat dimanfaatkan dengan metode daur ulang maupun berbagai pengolahan kembali secara fisik, dapat menggunakan sistem penimbunan secara alami dengan media tanah dan menunggu waktu untuk dapat terurai.

4) Metode Pemulihan Energi

$\begin{array}{rlr}\text { Kandungan } & \text { energi } & \text { yang } \\ \text { terkandung dalam } & \text { sampah bisa }\end{array}$
diambil langsung dengan cara menjadikannya bahan bakar atau secara tidak langsung dengan cara mengolahnya menjadi bahan bakar tipe lain dan daur ulang melalui cara perlaukan panas. Pirolisa dan gasifikasi adalah dua bentuk perlakuan panas yang berhubungan ketika sampah dipanaskan pada suhu yang tinggi. Keadaan pengolahan yang memiliki kadar oksigen yang rendah maka pirolisa dari sampah padat akan mengubah sampah menjadi produk berzat padat, gas dan cair.

5) Metode Penghindaran dan Pengurangan

Sebuah metode yang penting dari pengolahan sampah adalah pencegahan zat sampah terbentuk atau dikenal juga dengan pengurangan sampah. Kegiatan pengurangan sampah meliputi penggunaan kembali barang bekas pakai, memperbaiki barang yang rusak, mendesain produk agar dapat diisi ulang atau digunakan kembali dan mendesain produk menggunakan bahan yang lebih sedikit dengan fungi yang sama.
Pengelolaan sampah terdiri dari beberapa proses yang biasanya dimulai dari proses pewadahan sampah, pengumpulan sampah, pemindahan dan pengangkutan sampah, pengolahan atau pemrosesan sampah (bisa dengan daur ulang sampah yang dapat di daur ulang) hingga akhirnya pada tahapan pembuangan akhir sampah. Istilah pengelolaan sampah pada dasarnya dimaksudkan terhadap sampah yang dikelola yang berguna agar dapat mengurangi dampak negatifnya terhadap lingkungan sekitar, kesehatan, estetika lingkungan serta memberikan kenyamanan.

\section{Partisipasi masjid dalam tata kelola sampah pedesaan}

Temuan peneliti di lapangan menunjukkan bahwa partisipasi masjid dalam tata kelola sampah pedesaan sangat tinggi hal ini ditandai dengan ikut serta masyarakat dalam rembuk warga yang difasilitasi oleh Desa dan di laksanakan oleh warga Dusun Jenisari Desa Genteng Kulon. Rembuk warga ini dilakukan untuk menemukan titik temu atas permasalahan yang ada di Desa Khususnya terkait dengan pengelolaan sampah di Desa Genteng Kulon. Kegiatan ini dilakukan juga untuk pengambilan keputusan di tingkat Desa. Rembuk warga atau musyawarah Masyarakat ini melibatkan semua elemen masyarakat mulai dari takmir masjid, remaja masjid dan tokoh agama serta Kepala Desa, perangkat Desa dan Kepala Dusun di Desa Genteng Kulon.

Tokoh agama di Dusun Jenisari Desa Genteng Kulon sangat ditaati dan dijadikan panutan oleh hampir seluruh masyarakat. KH.Abdillah atau yang kerap disapa Gus Dillah merupakan motor dari pergerakan masyarakat Dusun Jenisari. Dari tangan dingin beliaulah masyarakat sekitar masjid, Takmir Msjid bahkan Remaja Masjid menjadi sangat aktif dan peduli terhadap lingkungan sekitar masjid khususnya terkait dengan pengelolaan sampah.

Dari rembuk warga inilah dihasilkan keputusan-keputuasan di tingkat desa 
salah satunya pelatihan pengolahan sampah yang dilaksanakan dan didanai oleh Desa Genteng Kulon. Pelatihan pengolahan sampah ini dilaksanakan pada tanggal 10 Oktober 2016 dihadiri 35 peserta dari lima Dusun yang ada di Desa Genteng Kulon. Pelatihan ini dilaksanakan di kawasan masjid Baitul Izzah dan dihadiri oleh masyarakat Desa Genteng Kulon serta jajaran pengurus takmir masjid Baitul Izzah dan para remaja masjid.

Kegiatan ini mampu menghasilkan solusi dari permasalahan tersebut. Memang disadari, sebagian besar masyarakat awalnya belum memahami hak-hak mereka, terutama dalam kebijakan publik, karena berpuluh tahun mereka dipinggirkan dalam pembuatan keputusan publik. Sebagian dari mereka awalnya menolak dan menganggap itu hanya urusan pemerintah saja. Namun setelah diyakinkan bahwa mereka memiliki hak untuk terlibat dan itu tertera dalam Undang-Undang akhirnya partisipasi itu muncul walaupun awalnya hal ini sulit diwujudkan.

Upaya-upaya untuk meningkatkan kesadaran dan pengetahuan masyarakat terhadap haknya seharusnya dilakukan oleh para pegiat organisasi masyarakat sipil dengan melakukan pendampingan agar warga paham dan dapat menggunakan haknya untuk terlibat dalam pembuatan kebijakan publik. Pendampingan ini dilakukan mulai dari mengeksplorasi masalah yang dihadapi warga, menentukan prioritas masalah yang perlu diselesaikan, mengelaborasi alternatif-alternatif solusi hingga formulasi kebijakan. Meski dengan berbagai keterbatasan dana, ternyata ada beberapa permasalahan warga yang kemudian berhasil diformulasikan menjadi sebuah draft kebijakan publik, berupa rancangan peraturan daerah (raperda).

Temuan peneliti mendapati bahwa hak warga masyarakat Desa Genteng Kulon untuk berpartisipasi ternyata diikuti dengan kehadiran pemerintah daerah membuka ruang partisipasi serta adanya sanksi terhadap aparat pemerintah yang tidak melibatkan masyarakat dalam pembuatan kebijakan publik. Hal ini terjadi, karena adanya mekanisme yang rinci dan jelas mengenai pelibatan masyarakat dalam kebijakan publik, yang meliputi mekanisme penyampaian aspirasi dalam rembuk warga dan mekanisme pengawasan. Desa Genteng kulon juga hadir di tengah masyarakat dengan mengundang masyarakat untuk hadir dalam pelatihan pengolahan sampah. Pelatihan ini dilaksanakan di Lingkungan Masjid Baitul Izzah Dusun Jenisari Desa Genteng Kulon yang dihadiri oleh 35 peserta yang meliputi takmir masjid, remas dan masyarakat Desa Genteng Kulon.

\section{KESIMPULAN}

Berdasarkan penelitian yang telah dilakukan oleh tim kami maka dapat dijelaskan bahwa tingkat partisipasi takmir masjid dan masyarakat sekitar masjid sangat tinggi. Hal ini dibuktikan dengan ikut sertanya masyarakat dalam menjaga lingkungan dan partispasi mereka dalam merumuskan kebijakan di tingkat desa berupa rembuk warga. Dalam rembuk warga ini di hasilkan jawaban-jawaban atas persoalanpersoalan yang dihadapi masyarakat.

Partisipasi masyarakat sekitar masjid dan takmir masjid Baitul Izzah yang cukup tinggi ternyata dibarengi dengan kehadiran Pemerintah Desa dalam memahamkan hak dan kewajiban masyarakat serta meningkatkan partisipasi mereka. Pelatihan pengolahan sampah yang dilaksanakan pada tanggal 10 oktober 2016 di lingkungan masjid Baitul Izzah yang diikuti oleh 35 warga yang terdiri dari masyarakat sekitar masjid, takmir masjid dan remas masjid menjadi bukti bahwa Pemerintah Desa Genteng Kulon hadir di tengah masyarakat. 
Nidhomul Haq Vol 3 No: 1 Maret 2018

ISSN 2503-1481

\section{DAFTAR PUSTAKA}

Mikkelsen, Britha. 2006. Metode Penelitian Partisipatoris dan Upaya-Upaya Pemberdayaan, Jakarta: Yayasan Obor Indonesia.

Juliantara, Dadang. 2004. Pembaharuan Kabupaten Mewujudkan Kabupaten Partisipatif Mewujudkan Kabupaten Partisipatif. Yogyakarta: Pembaharuan.

SS, Khairuddin, 2000. Pembangunan Masyarakat. Yogyakarta. Liberty

Soetomo. 2008. Strategi-Strategi Pembangunan Masyarakat. Yogyakarta: Pustaka Pelajar.

Slamet. 2003. Pembangunan Masyarakat Berwawasan Partisipasi.Surakarta: Sebelas Maret University Press.

Subarna, Endang. 2014. Manfaat Pengelolaan Sampah Terpadu. Surakarta: Aryhaeko Sinergi Persada. 